\title{
Development of Polymerase Chain Reaction Assays for Detection of Listeria monocytogenes in Clinical Cerebrospinal Fluid Samples
}

\author{
K. JATON, ${ }^{1}$ R. SAHLI, ${ }^{2}$ AND J. BILLE ${ }^{1 *}$ \\ Centre National des Listeria ${ }^{1}$ and Department of Virology, ${ }^{2}$ Institute of Microbiology, \\ University Hospital, 1011 Lausanne, Switzerland
}

Received 17 December 1991/Accepted 1 May 1992

\begin{abstract}
In order to improve the diagnosis of Listeria meningitis or meningoencephalitis, especially in patients who have received antibiotics before their cerebrospinal fluid (CSF) has been examined, two assays for the detection of Listeria monocytogenes based on the polymerase chain reaction (PCR) were evaluated. After a standard PCR, the amplified DNA was detected either by a second round of PCR with internal primers followed by gel electrophoresis and ethidium bromide staining (nested PCR) or by dot blot hybridization to an internal digoxigenin-labeled probe (PCR-dot blot). For PCR, two sets of primers within the invasion-associated protein gene (iap gene) were chosen. They allowed for the highly specific detection of all $L$. monocytogenes reference strains tested (serotypes 1/2a, 1/2b, 1/2c, 3a, 3b, 3c, 4a, 4b, 4c, 4d, and 7). These primers did not detect amplification products from various other gram-positive or gram-negative bacterial DNAs or human DNA. The sensitivities of both assays were assessed on sterile CSF samples that were artificially seeded with serial dilutions of $L$. monocytogenes serotype $4 \mathrm{~b}$ cells. By both methods the limit of detection was $<10$ cells in the initial reaction. Since the nested PCR is more prone to contamination because of manipulation of the amplified products, a standard PCR assay followed by dot blot hybridization was applied to 52 CSF samples in a retrospective study. Of 28 CSF samples which were sterile or positive for bacteria other than Listeria species, 24 were PCR negative. In contrast, from 17 patients with culture-proven Listeria meningitis, 14 of 17 initial CSF samples were PCR positive, as were 3 of 7 culture-negative follow-up CSF samples taken after patients received antibiotics. These results support the usefulness of this approach in the diagnosis of Listeria meningitis, in particular, when antibiotic administration precedes culture of CSF.
\end{abstract}

The increase in the incidence of human listeriosis in developed countries and the recent association of severe Listeria monocytogenes infections with food-borne outbreaks have stimulated research on new diagnostic procedures. In humans, L. monocytogenes mainly causes meningitis, encephalitis, or septicemia in nonpregnant adults. When it infects the central nervous system, L. monocytogenes leads to severe disease with a high mortality rate (20 to $50 \%$ ) and neurological sequelae among the survivors. Therefore, this infection requires prompt recognition and therapy (21).

The diagnosis of Listeria meningitis, meningoencephalitis, or septicemia is based on the culture of cerebrospinal fluid (CSF) and blood. The direct examination of Gram-stained clinical specimens is generally of little value, because $L$. monocytogenes is often present in low numbers in some samples, particularly in CSF, at the time of presentation. Furthermore, in some cases, antibiotics have already been administered to the patient before the CSF can be cultured, thus hampering the diagnosis.

Use of polymerase chain reaction (PCR) technologies for the detection of low numbers of $L$. monocytogenes in food samples has been reported $(1,3,5,8,10,22)$. To our knowledge, no PCR has been tested with human clinical samples. Several genes specific for Listeria species, which could serve as targets in a PCR, have been sequenced $(6,7$, $9,15)$. One of them, the iap gene, encodes the invasionassociated protein p60 (11), which may be involved in the

\footnotetext{
* Corresponding author.
}

invasion process (12). Köhler et al. (11) showed that synthetic probes previously described as specific for the detection of the presumptive $\beta$-hemolysin gene of $L$. monocytogenes by colony hybridization (4) are in fact part of the iap gene. Therefore, the iap gene seems an appropriate target for the detection of $L$. monocytogenes by PCR.

We report here a description and comparison of two PCR assays for the detection of $L$. monocytogenes DNA in human CSF samples. The first assay is a two-step PCR followed by gel electrophoresis and ethidium bromide $(\mathrm{EtBr})$ staining (nested PCR), and the second one is a standard PCR followed by dot blot hybridization with a digoxigenin-labeled probe (PCR-dot blot). We found that the latter methodology is sensitive enough to detect fewer than 10 cells. Its application was suitable for the retrospective diagnosis of $L$. monocytogenes in 52 clinical CSF samples collected between 1983 and 1991.

\section{MATERIALS AND METHODS}

Bacterial strains. The following bacterial strains were used in this study: (i) 18 reference or type strains representing all known Listeria species and all L. monocytogenes serotypes (H. P. R. Seeliger, University of Würzburg, Würzburg, Germany) except $L$. monocytogenes serotype $4 \mathrm{ab}$ (Table 1 ); (ii) $16 \mathrm{~L}$. monocytogenes serotype $4 \mathrm{~b}$ strains isolated from different patients during the outbreak of listeriosis in Canton de Vaud (Switzerland) (2); one of them (strain K27) was used for the serial dilution assays; (iii) 15 strains of gram-positive bacteria other than Listeria species (Table 2); (iv) 7 strains of Haemophilus influenzae isolated from CSF samples in the 
TABLE 1. Species, serotypes, and source of the Listeria strains used in this study

\begin{tabular}{lcl}
\hline \multicolumn{1}{c}{ Species } & Serotype & \multicolumn{1}{c}{ Source $^{a}$} \\
\hline L. monocytogenes & $1 / 2 \mathrm{a}$ & NCTC 7973 \\
L. monocytogenes & $1 / 2 \mathrm{~b}$ & SLCC 2755 \\
L. monocytogenes & $1 / 2 \mathrm{c}$ & NCTC 5348 \\
L. monocytogenes & $3 \mathrm{a}$ & NCTC 5105 \\
L. monocytogenes & 3b & SLCC 2540 \\
L. monocytogenes & $3 \mathrm{c}$ & SLCC 2479 \\
L. monocytogenes & $4 \mathrm{a}$ & NCTC 5214 \\
L. monocytogenes & $4 \mathrm{~b}$ & NCTC 10527 \\
L. monocytogenes & $4 \mathrm{c}$ & NCTC 4883 \\
L. monocytogenes & $4 \mathrm{~d}$ & ATCC 10888 \\
L. monocytogenes & $4 \mathrm{e}$ & ATCC 19118 \\
L. monocytogenes & 7 & SLCC 2482 \\
L. innocua & $6 \mathrm{a}$ & NCTC 11288 \\
L. ivanovii & 5 & ATCC 19119 \\
L. welshimeri & $6 \mathrm{a}$ & SLCC 5334 \\
L. seeligeri & $1 / 2 \mathrm{~b}$ & CIP 100100 \\
L. murrayi & & ATCC 25403 \\
L. grayi & & ATCC 19120 \\
& & \\
L. monocytogenes $(16$ & $4 \mathrm{~b}$ & Human clinical isolates \\
strains including K27) & & \\
\hline
\end{tabular}

${ }^{a}$ NCTC, National Culture Type Collection, Central Public Health Laboratory, London, England; SLCC, Special Listeria Culture Collection, Würzburg, Germany; ATCC, American Type Culture Collection, Rockville, Md.; CIP, Institut Pasteur Collection, Paris, France.

${ }^{b}$ The 16 strains were wild-type strains. All other strains listed here were reference or type strains.

Centre Hospitalier Universitaire Vaudois and 2 strains of Neisseria meningitidis.

All strains were kept in skim milk at $-80^{\circ} \mathrm{C}$. They were streaked onto $5 \%$ human blood Columbia agar (Oxoid, Unipath Ltd., Basingstoke, England). $H$. influenzae and $N$. meningitidis strains were streaked onto chocolate Columbia blood agar (Oxoid). All the plates were incubated for $24 \mathrm{~h}$ at $37^{\circ} \mathrm{C}$. One colony was then inoculated in Todd-Hewitt broth (Difco Laboratories, Detroit, Mich.) and was incubated overnight at $37^{\circ} \mathrm{C}$ before DNA preparation.

Human CSF samples. A total of 52 CSF samples from 44

TABLE 2. Genus, species, and source of bacteria other than Listeria species used in this study

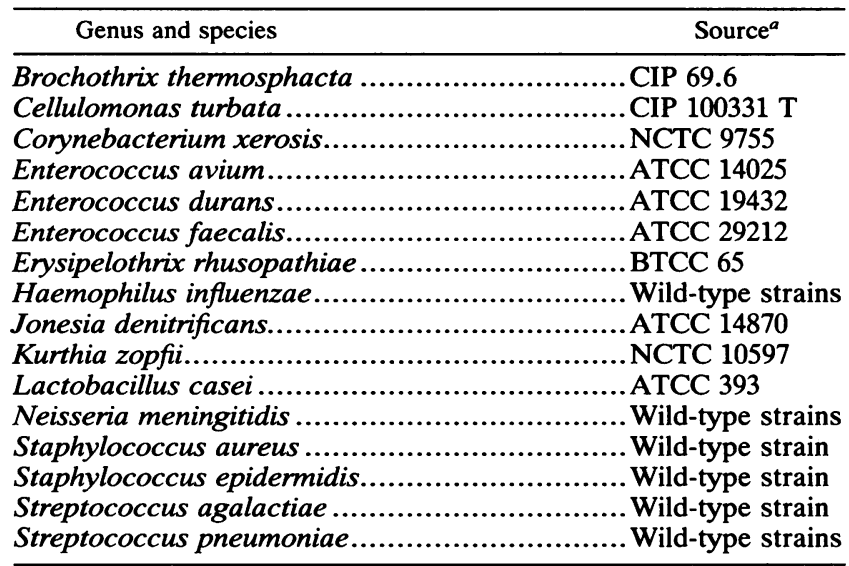

a CIP, Institut Pasteur Collection, Paris, France; NCTC, National Culture Type Collection, Central Public Health Laboratory, London, England, ATCC, American Type Culture Collection, Rockville, Md.; BTCC, Bulgarian Type Culture Collection, Sofia, Bulgaria. patients were tested (see Table 4), as follows: (i) 14 sterile CSF samples from 13 patients with nonbacterial meningitis or no CSF infection; half of them were collected during the Swiss outbreak of listeriosis (1983 to 1987) (2); (ii) 14 CSF samples positive for microorganisms other than Listeria species, as follows: $N$. meningitidis $(n=2)$, Staphylococcus aureus $(n=1)$, Staphylococcus epidermidis $(n=2)$, Streptococcus agalactiae $(n=1)$, Streptococcus pneumoniae (n $=2), H$. influenzae $(n=5)$, and Cryptococcus neoformans $(n=1) ; 10$ of the samples were collected during 1983 to 1987 , two were collected in 1988, and two were collected in 1991; (iii) 24 CSF samples from 17 patients with culture-proven Listeria meningitis; 17 samples were positive for L. monocytogenes by culture at the time of presentation; the other 7 samples were negative by culture and were follow-up samples taken between 2 and 15 days after the patient had started antibiotic treatment. All CSF samples except two were collected during the Swiss outbreak of listeriosis (1983 to 1987) (2).

All specimens were divided into aliquots and were stored at $-20^{\circ} \mathrm{C}$ without any particular precautions, as would now be required for studies involving PCR $(13,18)$.

DNA preparation. (i) DNA extraction. DNA was purified from bacteria by the method of Le Febvre et al. (14), with some modifications (16). Cells from a $1.5-\mathrm{ml}$ overnight culture or from chocolate agar plates incubated overnight were harvested and washed in $10 \mathrm{mM}$ Tris- $\mathrm{HCl}(\mathrm{pH} \mathrm{8.0)-1}$ $\mathrm{mM}$ EDTA-100 $\mathrm{mM} \mathrm{NaCl}$. After centrifugation the pellets were resuspended in $25 \mathrm{mM}$ Tris- $\mathrm{HCl}$ (pH 8.0)-10 mM EDTA-50 mM glucose. Cells were then treated with lysozyme (Sigma Chemical Co., St. Louis, Mo.) at $10 \mathrm{mg} / \mathrm{ml}$ and RNase A (Boehringer, GmbH, Mannheim, Germany) at 200 $\mu \mathrm{g} / \mathrm{ml}$ at $37^{\circ} \mathrm{C}$ for $30 \mathrm{~min}$. Proteinase $\mathrm{K}$ (Sigma) and sodium dodecyl sulfate were then added at $200 \mu \mathrm{g} / \mathrm{ml}$ and $1 \%$ (wt/vol), respectively, and the samples were incubated at $50^{\circ} \mathrm{C}$ for $60 \mathrm{~min}$. DNA was extracted three times with 1 volume of phenol-chloroform-isoamyl alcohol (25/24/1). The aqueous phase was recovered and adjusted to $0.3 \mathrm{M}$ sodium acetate, and nucleic acids were precipitated with 0.6 volume of isopropanol at room temperature for $5 \mathrm{~min}$. The DNA was centrifuged, washed with $70 \%$ ethanol, and air dried. The pellets were resuspended in $40 \mu \mathrm{l}$ of $10 \mathrm{mM}$ Tris- $\mathrm{HCl}-0.1$ mM EDTA (pH 7.5). For quantification, DNA was electrophoresed through a $0.8 \%$ agarose gel containing $0.5 \mu \mathrm{g}$ of EtBr per ml. The DNA was then revealed under UV light, and the fluorescence of the bacterial band was compared with that of a known amount of HindIII-digested bacteriophage $\lambda$ DNA.

(ii) Crude lysates of bacterial cells. Cells of $L$. monocytogenes serotype $4 \mathrm{~b}$ (human isolate $\mathrm{K} 27$ ) from an overnight culture were serially diluted in $500 \mu \mathrm{l}$ of sterile $0.9 \% \mathrm{NaCl}$. After centrifugation for $10 \mathrm{~min}$ in an Eppendorf centrifuge, the pellet from each dilution was resuspended in $1 \mathrm{ml}$ of sterile water and $10 \mu \mathrm{l}$ of each suspension was plated onto blood agar for CFU counts. The suspension was then left for $1 \mathrm{~h}$ at room temperature prior to DNA release by boiling for $10 \mathrm{~min}$. PCR was done with $10 \mu \mathrm{l}$ of the lysate.

(iii) Artificially seeded CSF samples. L. monocytogenes serotype $4 \mathrm{~b}$ (human isolate $\mathrm{K} 27$ ) from an overnight culture was serially diluted in $200 \mu \mathrm{l}$ of pooled sterile human CSF containing between 50 and $500 \times 10^{6}$ leukocytes per liter. After centrifugation for $10 \mathrm{~min}$, the pellet of each dilution was suspended in $100 \mu \mathrm{l}$ of sterile water and $10 \mu \mathrm{l}$ of each suspension was plated onto blood agar for CFU counts. Each dilution was then left at room temperature for $1 \mathrm{~h}$. Since bacteria were in a small volume, their DNA was 
TABLE 3. Sequences of the oligonucleotide primers and their locations in the iap gene

\begin{tabular}{|c|c|c|c|}
\hline Name & Sequence $\left(5^{\prime}\right.$ to $\left.3^{\prime}\right)$ & Location & $\begin{array}{l}\text { Product } \\
\text { (bp) }\end{array}$ \\
\hline $\begin{array}{c}\text { External } \\
\text { iap- } A \\
\text { iap- } B\end{array}$ & $\begin{array}{l}\text { CAAAGGTGGAT }{ }^{a} \mathrm{CC}^{a} \text { AAAGTAACTGT } \\
\text { TGGAGCTTCCGA }{ }^{a} \mathrm{~A}^{a} \text { TTCACTTCTG }\end{array}$ & $\begin{array}{c}760-783 \\
1228-1206\end{array}$ & 468 \\
\hline $\begin{array}{c}\text { Internal } \\
\text { iap-1 } \\
\text { iap-3 }\end{array}$ & $\begin{array}{l}\text { CGAATCTAACGGCTGGCACA } \\
\text { GCCCAAATAGTGTCACCGCT }\end{array}$ & $\begin{array}{c}793-812 \\
1080-1061\end{array}$ & 287 \\
\hline
\end{tabular}

${ }^{a}$ One mismatch was introduced at these positions for cloning purposes.

released by freezing at $-80^{\circ} \mathrm{C}$ and boiling five times for $30 \mathrm{~s}$ each time rather then boiling once for $10 \mathrm{~min}$. PCR was done with $10 \mu$ l of the lysate.

(iv) Human CSF samples. Two hundred microliters of CSF was centrifuged for $10 \mathrm{~min}$ in an Eppendorf centrifuge. The pellets were suspended in $100 \mu \mathrm{l}$ of sterile water, and DNA was released by freezing and boiling five times as described above. PCR was done with $10 \mu$ l of the lysate. All samples were tested at least twice.

PCR. (i) Oligonucleotide characteristics. Primers were chosen from the invasion-associated protein gene (iap gene) on the basis of the sequence reported by Köhler et al. (11). Specific data on the two pairs of oligonucleotide primers are given in Table 3. The external primers iap- $A$ and iap-B delimit a 468-bp segment of the iap gene of $L$. monocytogenes. The internal primers iap-1 and iap-3 delimit a 287-bp segment within the 468 -bp product. iap-3 was used as a probe in the dot blot assay to identify the PCR product obtained with the external primers (iap-A and iap-B).

(ii) Standard PCR. PCR (19) amplification was performed with $10 \mu \mathrm{l}$ of DNA preparation in a $50-\mu$ l reaction containing $50 \mathrm{mM}$ Tris- $\mathrm{HCl}$ (pH 8.8)-1.5 mM MgCl${ }_{2}-50 \mathrm{mM} \mathrm{KCl}-0.01 \%$ gelatin- $0.1 \%$ Triton $\mathrm{X}-100,200 \mu \mathrm{M}$ (each) four deoxynucleotide triphosphates, and primers iap- $A$ and iap-B or iap-1 and iap-3 at 0.8 or $1 \mu \mathrm{M}$, respectively. The samples were overlaid with $50 \mu$ l of paraffin oil. The PCR was done with a Techne PHC 2 thermal cycler. Positive $(0.05 \mathrm{ng}$ of $L$. monocytogenes serotype 4b DNA) and negative (no DNA) controls were included in each set of PCRs.

(iii) Cycling. The precycle consisted of $97^{\circ} \mathrm{C}$ for $5 \mathrm{~min}$ and $74^{\circ} \mathrm{C}$ for $1 \mathrm{~min}, 1 \mathrm{U}$ of $\mathrm{Taq}$ polymerase (Cetus) was added, annealing was done at $50^{\circ} \mathrm{C}$ for $1 \mathrm{~min}$, and extension was done at $74^{\circ} \mathrm{C}$ for $2 \mathrm{~min}$. For cycles 1 to 30 , denaturation was done at $94^{\circ} \mathrm{C}$ for $30 \mathrm{~s}$, primer annealing was done at $50^{\circ} \mathrm{C}$ for $1 \mathrm{~min}$, and extension was done at $74^{\circ} \mathrm{C}$ for $1 \mathrm{~min}$, with an additional extension step at $74^{\circ} \mathrm{C}$ for $5 \mathrm{~min}$ at the end of the last cycle.

(iv) Nested PCR. A new PCR was performed by using $10 \mu \mathrm{l}$ of the standard PCR as a template. Buffer, deoxynucleotide triphosphates, internal primers iap-1 and iap-3 at $1 \mu \mathrm{M}$, and Taq polymerase were added. The reactions were then subjected to an additional 30 cycles of amplification as described above.

(v) Negative controls. At the time of DNA preparation, every fourth or fifth sample was an internal negative control, in which water replaced DNA. All the clinical CSF samples were given a code and assayed by one of the investigators (K.J.), who was unaware of the culture results. The samples that were negative by the standard PCR were tested for inhibitors. For this, human placental DNA (1 ng) was added to the CSF sample together with human leukocyte antigen
DQ $\alpha$ primers (20), and PCR was done by using the same conditions as those for the standard PCR. The target of these primers was the human leukocyte antigen locus. An amplified product of $227 \mathrm{bp}$ was expected if no inhibitors of the amplification were present in the sample.

Detection of the amplification products. (i) Electrophoresis and ethidium bromide staining. Ten microliters of each reaction was electrophoresed for approximately $30 \mathrm{~min}$ at 10 $\mathrm{V} / \mathrm{cm}$ through a $3 \%$ Nusieve GTG agarose gel (FMC Bioproducts, Rockland, Maine) containing $0.5 \mu \mathrm{g}$ of EtBr per ml. DNA was revealed under UV light.

(ii) Dot blot hybridization. Three microliters of the amplified product of the standard PCR was applied to a nylon membrane (Boehringer). DNA was denatured in $0.5 \mathrm{~N}$ $\mathrm{NaOH}-1.5 \mathrm{M} \mathrm{NaCl}$ for $5 \mathrm{~min}$ and was then neutralized with $1 \mathrm{M}$ Tris- $\mathrm{HCl}(\mathrm{pH} \mathrm{7.5)-1.5} \mathrm{M} \mathrm{NaCl}$ three times for $2 \mathrm{~min}$ each time. The membrane was then rinsed in $2 \times \mathrm{SSC}(1 \times$ SSC is $0.15 \mathrm{M} \mathrm{NaCl}$ plus $0.015 \mathrm{M}$ sodium citrate) for $2 \mathrm{~min}$ and was baked at $120^{\circ} \mathrm{C}$ for $30 \mathrm{~min}$. Prehybridization was performed at $52^{\circ} \mathrm{C}$ for more than $1 \mathrm{~h}$ in $3 \mathrm{M}$ tetramethylammoniumchloride (TMAC)-50 mM Tris- $\mathrm{HCl}$ (pH 8.0)-1\% blocking reagent (Boehringer) $-0.02 \%$ sodium dodecyl sulfate- $0.1 \% N$-lauryl sarcoside-50 $\mu \mathrm{g}$ of salmon sperm DNA per $\mathrm{ml}$. The prehybridization solution was then replaced with an identical solution containing the iap-3 probe at $1 \mathrm{nM}$, and hybridization was allowed to proceed for more than $2 \mathrm{~h}$ at $52^{\circ} \mathrm{C}$. The probe was prepared by labeling the $3^{\prime}$ end of the internal primer iap-3 with digoxigenin-dUTP by using terminal transferase as recommended by the manufacturer (Boehringer). After the hybridization, the membrane was washed twice at $62^{\circ} \mathrm{C}$ for $15 \mathrm{~min}$ in $3 \mathrm{M} \mathrm{TMAC}-50 \mathrm{mM}$ Tris- $\mathrm{HCl}$ ( $\mathrm{pH} \mathrm{8.0).} \mathrm{Immunoenzymatic} \mathrm{detection} \mathrm{of} \mathrm{the} \mathrm{hy-}$ bridized probe was performed with an anti-digoxigenin antibody coupled to alkaline phosphatase by using $3-\left(2^{\prime}-\right.$ spiroadamantane)-4-methoxy-4-(3'-phosphoryloxy)-phenyl1,2-dioxetane (AMPPD; Boehringer) as a substrate, as recommended by the manufacturer. The chemiluminescence reaction was revealed by exposure of the membrane to X-ray film for $2 \mathrm{~h}$.

\section{RESULTS}

We used the PCR methodology to improve the diagnosis of $L$. monocytogenes meningitis. Initially, 30 cycles of PCR (standard PCR) were performed with 10 -fold dilutions of $L$. monocytogenes DNA (from 5 to $0.05 \mathrm{ng}$, corresponding to $10^{6}$ to $10^{4}$ cells, respectively) by using the external primers iap- $A$ and iap-B or the internal primers iap-1 and iap-3. The amplification products were clearly detectable after agarose gel electrophoresis and EtBr staining (Fig. 1). To assess whether these primers were specific for $L$. monocytogenes, $0.05 \mathrm{ng}$ of DNA from 34 Listeria strains and 24 non-Listeria strains was used as template for the PCR. DNA from strains representing all serotypes of $L$. monocytogenes gave a single amplified product of the expected size. For $L$. ivanovii ATCC 19119 and L. welshimeri SLCC 5334, DNA could be amplified with the external primers, whereas no product was found with the internal primers. This suggests that iap- $A$ and iap- $B$ are not specific for $L$. monocytogenes, whereas iap- 1 and iap-3 are. Therefore, the specificity for $L$. monocytogenes detection is provided by the iap-1 and iap-3 primers. No amplification products were detectable with DNA from 7 $H$. influenzae strains, $2 N$. meningitidis strains, or 15 grampositive bacteria other than Listeria species or with human DNA.

To determine the level of sensitivity of the standard PCR 


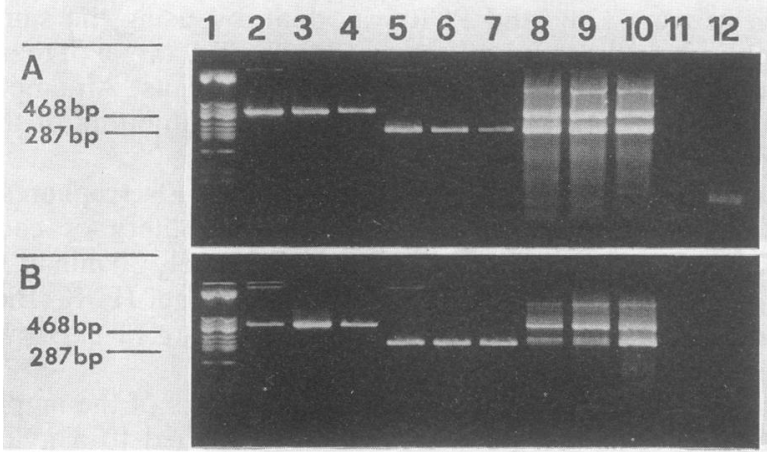

FIG. 1. Agarose gel electrophoresis of PCR-amplified products from 10 -fold dilutions of lysates of $L$. monocytogenes serotype $4 \mathrm{~b}$ cells (strain K27) ranging from $10^{6}$ to $10^{4}$ cells (A) and DNA extracted from $L$. monocytogenes ranging from 5 to $0.05 \mathrm{ng}(\mathrm{B})$. Lane 1, molecular size markers; lanes 2 to 4 , standard PCR with the external primers iap- $A$ and iap-B; lanes 5 to 7 , standard PCR with the internal primers iap- 1 and iap-3; lanes 8 to 10 , nested PCR; lane 11, negative control of the standard PCR; lane 12, negative control of the nested PCR.

assay, serial dilutions of DNA of a human L. monocytogenes serotype $4 \mathrm{~b}$ strain (K27) were used as templates with either the external primers (Fig. 2A) or the internal primers (Fig. 2B). After 30 cycles of amplification, the specific products were still detectable by EtBr staining when $5 \times 10^{-3} \mathrm{ng}$ of DNA (corresponding to $10^{3}$ cells) served as template. Since this level of sensitivity was not satisfactory, we improved it using the nested primer methodology (nested PCR).

L. monocytogenes DNA from an aliquot of the reaction done with the external primers was reamplified for an additional 30 cycles by using the internal primers iap- 1 and iap-3. An aliquot of the reaction was then submitted to gel electrophoresis, and the DNA was stained with EtBr. The specific 287-bp amplification product was still detected when DNA corresponding to $5 \times 10^{-5} \mathrm{ng}$ (equivalent to 10 cells) was used as a template in the reaction (Fig. 2C). The level of detection was thus enhanced at least 100 -fold up to the theoretical detection limit with this nested-PCR procedure

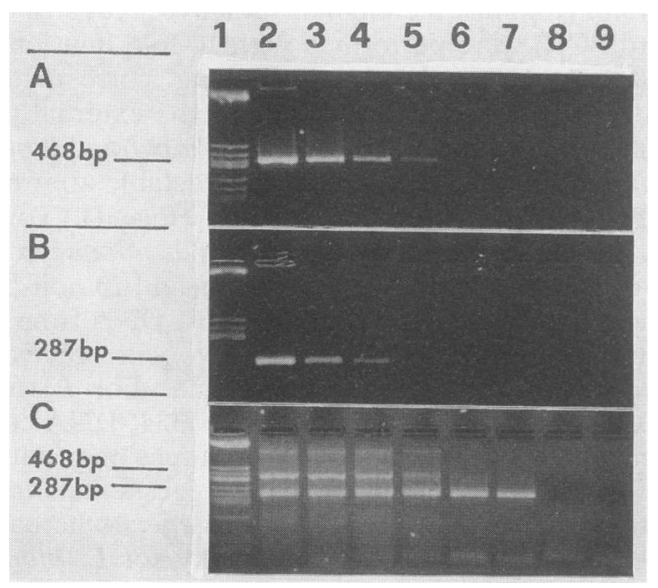

FIG. 2. Agarose gel electrophoresis of PCR-amplified products from 10-fold dilutions of purified $L$. monocytogenes DNA. (A) Standard PCR with iap- $A$ and iap-B primers giving a 468 -bp product. (B) Standard PCR with iap-1 and iap-3 primers giving a 287-bp product. (C) Nested PCR. Lane 1, molecular size markers; lanes 2 to 8 , dilutions ranging from 5 to $5 \times 10^{-6} \mathrm{ng}$; lane 9 , negative controls.

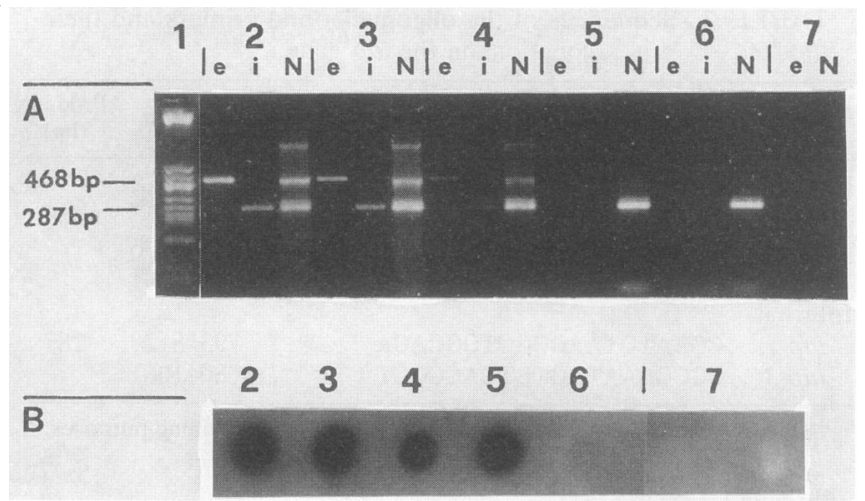

FIG. 3. (A) Agarose gel electrophoresis of PCR-amplified products from CSF artificially seeded with 10-fold dilutions of $L$. monocytogenes cells. Lane 1, molecular size markers; lanes 2 to 6 , dilutions of $L$. monocytogenes cells ranging from $4 \times 10^{4}$ to 4 cells; lane 7, negative controls of the standard PCR and the nested PCR; lanes $\mathrm{e}$, standard PCR with the external primers iap- $A$ and iap- $B$; lanes $\mathrm{i}$, standard PCR with the internal primers iap-1 and iap-3; lanes $\mathrm{N}$, nested PCR. (B) Dot blot analysis of the amplified products from the standard PCR. Lanes 2 to 7 are the same as those described above for panel A.

compared with that of the standard PCR. When dilutions of crude $L$. monocytogenes cell lysates instead of purified DNA were used in the PCR, the sensitivity level was the same (data not shown).

Detection of $L$. monocytogenes in artificially seeded CSF samples. In order to mimic a clinical situation, sterile CSF samples were artificially seeded with serial dilutions of $L$. monocytogenes serotype $4 \mathrm{~b}$ (strain K27). Four hundred bacteria corresponding to $2 \times 10^{4}$ cells per ml of CSF were detectable by the standard PCR assay after electrophoresis and EtBr staining (Fig. 3, lanes e and i). By the nested PCR approach, as few as four bacteria, corresponding to 200 cells per $\mathrm{ml}$ of CSF, were detectable, again increasing the sensitivity to its theoretical limit (Fig. 3, lanes N). Since this procedure involves handling of amplified DNA, it is more prone to contamination and may not be suitable. Therefore, to increase the sensitivity without increasing the risk of contamination, a more sensitive method was used to detect the amplification product of the standard PCR. For this, the internal primer iap-3 was labeled with digoxigenin and was used as a probe for the detection of the 468-bp amplified product in a dot blot assay (PCR-dot blot). With this nonradioactive probe, 4 cells (equivalent to 200 cells per $\mathrm{ml}$ of CSF) were detected (Fig. 3B). This level of sensitivity was the same as that for the nested PCR procedure.

Application of the PCR and dot blot methodology to clinical CSF samples. The PCR-dot blot methodology was used for the detection of $L$. monocytogenes in $52 \mathrm{CSF}$ samples (Table 4 and Fig. 4). All 14 sterile CSF samples from patients without meningitis were PCR-dot blot negative (Table 4).

Of 14 CSF samples that were positive for microorganisms other than $L$. monocytogenes, 10 were negative by PCR-dot blot, whereas 4 were positive (Table 4). All four were culture positive for $H$. influenzae and represented false-positive specimens under our experimental conditions. The DNAs extracted from the corresponding four $H$. influenzae strains were tested by PCR, dot blot, and Southern blot analyses. None of the DNAs could be detected, thus excluding nonspecific amplification with the iap- $A$ and iap- $B$ primers and nonspecific hybridization of the iap-3 probe (data not 
TABLE 4. Detection of $L$. monocytogenes in clinical CSF samples by comparison of conventional culture and PCR-dot blot

\begin{tabular}{lccc}
\hline $\begin{array}{c}\text { CSF samples } \\
\text { (no. of samples; no. of patients) }\end{array}$ & $\begin{array}{c}\text { No. of } \\
\text { samples } \\
\text { (Total } n=52)\end{array}$ & Culture & $\begin{array}{c}\text { PCR-dot } \\
\text { blot }\end{array}$ \\
\hline Sterile CSF $(14 ; 14)$ & 14 & - & - \\
CSF positive for organisms other & 10 & - & - \\
$\quad$ than $L$. monocytogenes $(14 ; 13)$ & 4 & - & + \\
CSF from patients with culture- & 14 & + & + \\
$\quad \begin{array}{l}\text { confirmed Listeria meningitis } \\
(24 ; 17)\end{array}$ & 4 & - & - \\
& 3 & + & - \\
& 3 & - & + \\
\hline
\end{tabular}

shown). In addition, all PCR-negative controls (in two independent PCR runs) were negative, thus reasonably excluding contamination at the time of the PCR assay. These CSF samples may have been contaminated previously during storage and/or manipulation.

Of 24 CSF samples collected from 17 patients with cultureconfirmed Listeria meningitis, 14 were PCR-dot blot hybridization and culture positive and four were negative by both techniques (Table 4).

Three other CSF samples which were culture positive for L. monocytogenes remained PCR-dot blot negative. One was a supernatant from the original CSF sample. The second was positive in one broth only after $72 \mathrm{~h}$. The third PCR-dot blot false-negative CSF sample probably contained very few bacteria because none of two solid media and one of two broth culture media only was positive at the time of presentation. No PCR inhibitors could be found in these three samples or in any other negative samples. DNA from the $L$. monocytogenes strains in two of these CSF samples was extracted, and $0.5 \mathrm{ng}$ of this DNA was submitted to the PCR-dot blot methodology. A strong positive signal was obtained, suggesting that these false-negative results were not due to a lack of specificity of our primers. These negative results by PCR-dot blot probably reflect the low concentrations of $L$. monocytogenes in these CSF samples (fewer than 400 cells per $\mathrm{ml}$ ). Finally, three other samples negative by culture were positive by PCR-dot blot. All three samples

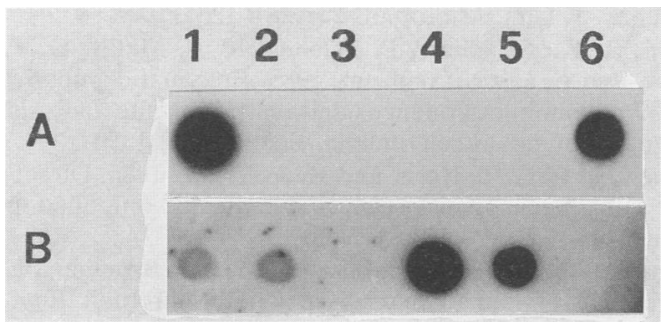

FIG. 4. Dot blot analysis of amplified CSF samples probed with digoxigenin-labeled iap-3 oligonucleotide. (A) Lane 1, positive control; lane $2, H$. influenzae culture-positive CSF (false-positive result); lane $3, C$. neoformans culture-positive CSF; lane $4, N$. meningitidis culture-positive CSF; lane 5 , sterile CSF; lane 6 , positive control. (B) Lane 1, L. monocytogenes serotype $4 \mathrm{~b}$ culturepositive CSF; lane $2, L$. monocytogenes serotype $4 \mathrm{~b}$ culture-positive CSF; lane $3, L$. monocytogenes serotype $4 \mathrm{~b}$ culture-negative sample (follow-up of a positive CSF); lane 4, L. monocytogenes serotype $4 \mathrm{~b}$ culture-positive CSF; lane 5, L. monocytogenes serotype $4 \mathrm{~b}$ culturepositive CSF; lane 6, negative control. A2 and B3 were well seen on the original X-ray film. were follow-up CSF samples (2, 2, and 15 days, respectively) from patients with a previous CSF sample that was positive for $L$. monocytogenes by culture and who were already treated with antibiotics. These data suggest that nonviable cells can be detected by PCR-dot blot.

\section{DISCUSSION}

In order to improve the diagnosis of Listeria meningitis, especially after antibiotic administration, we developed and compared two PCR-based procedures. A nested PCR assay followed by gel electrophoresis and $\mathrm{EtBr}$ staining was compared with a standard PCR assay followed by dot blot hybridization. Two sets of primers were selected within the iap gene (11). The selected oligonucleotides allowed the detection of all $L$. monocytogenes reference strains tested. The external primers (iap-A and iap-B) were not specific for $L$. monocytogenes, because they allowed the amplification by PCR of DNA from two non-L. monocytogenes reference strains. However, the internal primers iap-1 and iap-3 provided specificity for the detection of $L$. monocytogenes by the nested PCR, with iap-3 providing the specificity for the dot blot hybridization assay. This difference between both pairs of primers was not surprising. It is known that the specificity of a PCR highly depends on the 3 '-end sequence of the primers and that one mismatch in this region may result in no amplification.

We, like others, have observed that purification of the bacterial DNA is not necessary for $\operatorname{PCR}(1,3,17)$. Thus, the use freeze-thaw lysates of CSF reduces the need for manipulation of the clinical samples and could diminish the risk of false-positive results because of contamination.

Under our experimental conditions, the standard PCR assay for the direct detection of $L$. monocytogenes had a sensitivity of 1,000 to 400 viable cells. Because the theoretical limit of detection by PCR is on the order of one copy of the target sequence initially in the reaction, we assessed whether this limit could be obtained. Indeed, this was achieved by increasing the number of amplification cycles in the nested methodology or by increasing the sensitivity of PCR product detection in the hybridization procedure. The nested PCR methodology can be completed in $8 \mathrm{~h}$. However, its routine application in a standard microbiological setting may be difficult because of the high risk of contamination $(13,18)$. Although the dot blot methodology is more timeconsuming (more than $24 \mathrm{~h}$ to complete), it is less susceptible to contamination. Thus, it may be more useful in a diagnostic laboratory.

For the reasons mentioned above, we chose the PCR-dot blot methodology to examine 52 CSF samples collected between 1983 and 1991. All four false-positive results obtained by PCR-dot blot were obtained with CSF samples which were positive by culture for $H$. influenzae. This was very intriguing but could not be explained by a lack of specificity of the reaction. When DNA from each of the four $H$. influenzae strains was used as a template in the PCR, no amplification product could be detected by Southern blotting or dot blotting with the iap-3 probe (data not shown). All the experiments were done at least twice, with negative controls performed at each step. Physical separation of the pre- and postamplification procedures, separate sets of supplies and pipetting devices for setting up reactions, and positivedisplacement pipettes were used to avoid contamination, 
according to current standards for performing DNA amplification $(13,18)$. Contamination during the performance of the assay couid thus be reasonably excluded. These falsepositive results might result from a contamination of the samples during collection, storage, and subsequent manipulations. They were all collected during the period of the Swiss outbreak of listeriosis (1983 to 1987) (2) and were manipulated in the same laboratory where the true-positive specimens and all the strains of $L$. monocytogenes related to the epidemic were investigated. At that time, the possibility of doing DNA amplification was not considered, and appropriate care was not necessarily applied to the sampling of the specimens. Our results stress the fact that clinical samples must be manipulated with special caution when a nucleic acid amplification assay is to be used.

A positive signal could be obtained with 14 of $17 \mathrm{CSF}$ samples positive for L. monocytogenes by culture and tested after 1 to 7 years of storage. Three additional specimens that were culture positive for $L$. monocytogenes were PCR-dot blot negative. No PCR inhibitors were found in these three false-negative specimens. The amount of $L$. monocytogenes could have been minimal in these samples, reaching the limit of sensitivity of the method.

Three other CSF samples collected from patients with Listeria meningitis were culture negative and PCR-dot blot positive. All three samples were follow-up CSF samples taken from patients with a previous CSF culture that was positive for $L$. monocytogenes, and who had already been treated for 2 or more days with antibiotics. In that situation, PCR-dot blot may be more sensitive than conventional culture because it can detect cells even though they are dead. For this reason, these results were not considered false positive. They suggest that standard PCR followed by dot blot hybridization is an encouraging approach for the diagnosis of Listeria meningitis, in particular, when antibiotic administration precedes culture of CSF.

\section{ACKNOWLEDGMENTS}

We thank Elisabeth Bannerman for the gift of strains, Dorota Nocera for the gift of DNA, Françoise Ischer for excellent technical help, and Phil Shaw for critical reading of the manuscript.

\section{REFERENCES}

1. Bessesen, M. T., Q. Luo, H. A. Rotbart, M. J. Blaser, and R. T. Ellison III. 1990. Detection of Listeria monocytogenes by using the polymerase chain reaction. Appl. Environ. Microbiol. 56: 2930-2932.

2. Bille, J. 1990. Epidemiology of human listeriosis in Europe, with special reference to the Swiss outbreak, p. 71-74. In A. J. Miller, J. L. Smith, and G. A. Somkuti (ed.), Foodborne listeriosis. Elsevier, New York.

3. Border, P. M., J. J. Howard, G. S. Plastow, and K. W. Siggens. 1990. Detection of Listeria species and Listeria monocytogenes using polymerase chain reaction. Lett. Appl. Microbiol. 11:158162.

4. Datta, A. R., B. A. Wentz, D. Shook, and M. W. Trucksess. 1988. Synthetic oligodeoxiribonucleotide probes for detection of Listeria monocytogenes. Appl. Environ. Microbiol. 54:29332937.

5. Deneer, H. G., and I. Boychuk. 1991. Species-specific detection of Listeria monocytogenes by DNA amplification. Appl. Environ. Microbiol. 57:606-609.

6. Domann, E., and T. Chakraborty. 1989. Nucleotide sequence of the listeriolysin gene from a Listeria monocytogenes serotype 1/2a. Nucleic Acids Res. 17:6406.

7. Flamm, R. K., D. J. Hinrichs, and M. F. Thomashow. 1989. Cloning of a gene encoding a major secreted polypeptide of Listeria monocytogenes and its potential use as a speciesspecific probe. Appl. Environ. Microbiol. 55:2251-2256.

8. Furrer, B., U. Candrian, C. Hoefelein, and J. Luethy. 1991. Detection and identification of Listeria monocytogenes in cooked sausage products and in milk by in vitro amplification of haemolysin gene fragments. J. Appl. Bacteriol. 70:372-379.

9. Göhmann, S., M. Leimeister-Wächter, E. Schlitz, W. Goebel, and T. Chakraborty. 1990. Characterization of a Listeria monocytogenes-specific protein capable of inducing delayed hypersensitivity in Listeria-immune mice. Mol. Microbiol. 4:10911099.

10. Golsteyn Thomas, E. J., R. K. King, J. Burchak, and V. P. J. Gannon. 1991. Sensitive and specific detection of Listeria monocytogenes in milk and ground beef with the polymerase chain reaction. Appl. Environ. Microbiol. 57:2576-2580.

11. Köhler, S., M. Leimeister-Wächter, T. Chakraborty, F. Lottspeich, and W. Goebel. 1990. The gene coding for protein p60 of Listeria monocytogenes and its use as a specific probe for Listeria monocytogenes. Infect. Immun. 58:1943-1950.

12. Kuhn, M., and W. Goebel. 1989. Identification of an extracellular protein of Listeria monocytogenes possibly involved in intracellular uptake by mammalian cells. Infect. Immun. 57:5561.

13. Kwok, S., and R. Higuchi. 1989. Avoiding false positives with PCR. Nature (London) 339:237-238.

14. Le Febvre, R. B., J. W. Foley, and A. B. Thiermann. 1985. Rapid and simplified protocol for isolation and characterization of leptospiral chromosomal DNA for taxonomy and diagnosis. J. Clin. Microbiol. 22:606-608.

15. Mengaud, J., M. F. Vicente, and P. Cossart. 1989. Transcriptional mapping and nucleotide sequence of the Listeria monocytogenes $h l y A$ region reveal structural features that may be involved in regulation. Infect. Immun. 57:3695-3701.

16. Nocera, D., E. Bannerman, J. Rocourt, K. Jaton-Ogay, and J. Bille. 1990. Characterization by DNA restriction endonuclease analysis of Listeria monocytogenes strains related to the Swiss epidemic of listeriosis. J. Clin. Microbiol. 28:2259-2263.

17. Patel, R. J., J. W. U. Fries, W. F. Piessens, and D. F. Wirth. 1990 . Sequence analysis and amplification by polymerase chain reaction of a cloned DNA fragment for identification of $\mathrm{Myco}$ bacterium tuberculosis. J. Clin. Microbiol. 28:513-518.

18. Persing, D. H. 1991. Polymerase chain reaction: trenches to benches. J. Clin. Microbiol. 29:1281-1285.

19. Saiki, R. K., S. Scharf, F. Faloona, K. B. Mullis, G. T. Horn, H. A. Erlich, and N. Arnheim. 1985. Enzymatic amplification of $\beta$-globin genomic sequences and restriction site analysis for the diagnosis of sickle-cell anemia. Science 230:1350-1354.

20. Scharf, S. J., G. T. Horn, and H. A. Erlich. 1986. Direct cloning and sequences analysis of enzymatically amplified genomic sequences. Science 233:1076-1078.

21. Schuchat, A., B. Swaminathan, and C. V. Broome. 1991. Epidemiology of human listeriosis. Clin. Microbiol. Rev. 4:169183.

22. Wernars, K., C. J. Heuvelman, T. Chakraborty, and S. H. W. Notermans. 1991. Use of the polymerase chain reaction for direct detection of Listeria monocytogenes in soft cheese. J. Appl. Bacteriol. 70:121-126. 